Mijo Korade

DOI: https://dx.doi.org/10.21857/y6zolbr50m Izvorni znanstveni članak

Rukopis prihvaćen za tisak: 11.12.2019.

\title{
OKOLNOSTI, IZVORI I DOMETI KATEKIZAMA ANTUNA KANIŽLIĆA
}

\section{Sažetak}

Antun Kanižlić objavio je dva katekizma koja su imala posve različitu sudbinu i nastala su pod različitim okolnostima, ali imaju jednaku vrijednost i ulogu u vjerskom i kulturnom ozračju Slavonije toga vremena. U izlaganju se osvjetljavaju i dopunjuju novim podacima okolnosti, izvori i dometi tih Kanižlićevih katekizama. Prvi je katekizam pod naslovom Obilato duhovno mliko. To jest Nauk krstjanski iliričkoj iliti slovinskoj dičici darovan (Zagreb 1754) nastao u povodu serije vizitacija i pučkih misija koje je zagrebački biskup Franjo Thauszy 1753. organizirao u požeškom kraju, a godinu ranije imenovao je Kanižlića prisjednikom biskupskog konzistorija u Požegi. Zato katekizam izlazi pod biskupovim imenom i on potpisuje nadahnut i poticajni predgovor. Po sadržaju slijedi strukturu Kanizijeva velikog katekizma s dubokim teološkim sadržajem, u obliku pitanja i odgovora u 25 poglavlja. Objašnjava se zašto je bio namijenjen župnicima i učiteljima te zašto nije imao kasnijih izdanja. Drugi je katekizam Mala i svakom potribna Bogoslovica. To jest Nauk kerstjanski u tri skule razdiljen, a prvo izdanje vjerojatno je izašlo 1760. i do 1818. je doživjelo ukupno sedam izdanja. On sadrži katekizam, molitve i pjesme, a nastaje u jeku analfabetske akcije koju je u požeškom kraju 1752. započeo Josip Milunović, prvih osnovnih škola u tom kraju i Bratovštine kršćanskog nauka koje od 1760. organiziraju i vode isusovci. Zato je i katekizam zapravo prerada njemačkog katekizma Ignacija Parhammera, inicijatora i promotora tog katehetskog pokreta u Austriji, koji u metodi slijedi Kanizijevu tradiciju.

Uz to 1761. u Zagrebu izlazi po sadržaju identičan katekizam: Nauk karstjanski sverhu pet poglavjah Petra Canizija Družbe Isusove na tri skule razdiljen... U naslovu se napominje da, osim katekizma, molitava i pjesama, sadrži i upute za Bratovštinu kršćanskog nauka te da ga je jedan isusovac dijelio iste godine u misijama. Bio je to Petar Lipovčić u misijama među bačkim Hrvatima, a opširni predgovor potpisao je kaločki nadbiskup grof Joseph Báttyany. On napominje da je na tim misijama uz preko 2.000 primjeraka katekizma dao razdijeliti i upute za nepismene. Isti katekizam $s$ istom namjenom ponovno je tiskan u Kaloči 1767. s napomenom da su ga misionari dijelili na misijama 1766. godine. Kanižlićevu Bogoslovicu priredio je na kajkavskom zagrebački 
kanonik Boltižar Mataković i objavio pod naslovom Naručna knižica navuka krščanskoga (Zagreb 1770).

Ključne riječi: Antun Kanižlić; Požega; Slavonija; 18. stoljeće; katekizmi; biskup Thauszy; pučke misije; opismenjavanje; Kaločka nadbiskupija.

\section{Uvod}

Oko sredine 18. stoljeća iz tiska je izišao priličan broj katekizama u kontinentalnom i sjevernom dijelu Hrvatske. Osim onih sasvim kratkih u molitvenicima, abecedicama i misijskim pjesmaricama, kakve je objavljivao tada najpopularniji propovjednik, pučki misionar i vjerski pisac Juraj Mulih na sva tri narječja, on je napisao i najviše velikih, srednjih i malih katekizama na kajkavskom i štokavskom jeziku. Više katekizama $u$ to vrijeme, originalnih ili prijevoda, objavljuju slavonski franjevci, kao Emerik Pavić, Šimun Mecić, Antun Bačić, Jerolim Lipovčić i drugi. Posebno mjesto u toj vrsti vjerske literature imaju dva katekizma Antuna Kanižlića, vrlo različita po stilu i sadržaju, a osobito po sudbini i izdanjima. Budući da u literaturi postoje različita tumačenja i dosta nedoumica o sudbini tih dvaju katekizama, potrebno je podrobnije analizirati okolnosti, izvore i domete tih Kanižlićevih djela.

\section{Obilato duhovno mliko, 1754.}

Okolnosti u kojima je nastao katekizam Obilato duhovno mliko povezane su sa zagrebačkim biskupom Franjom Thauszyjem (1698. - 1769.). Budući da je Thauszy već kao bosanski biskup od 1749. obilazio i obnavljao župe u slavonskom kraju koji je pripadao Bosanskoj biskupiji (Đakovo, Brod, Gradiška...), kada je 1751. imenovan zagrebačkim biskupom i potvrđen 1752., odmah na početku posvetio je osobitu pažnju slavonskom dijelu Zagrebačke biskupije za uređenje i napredak tamošnjih župa. Već iste 1752. godine biskup osniva posebno podružno upravno tijelo ili vijeće, tzv. subalterni konzistorij (consistorium subalternum) za slavonske župe. Prvi predsjednik (prisjednik) konzistorija bio je zagrebački kanonik Nikola Petričević, a bilježnik Pavao Vučetić. Jedan od članova vijeća od samoga početka i sve do svoje smrti (1777.) bio je isusovac Antun Kanižlić, a kroz mnogo godina i prisjednik vijeća.

Zadaća konzistorija bila je voditi i nadzirati sve duhovne i pastoralne poslove u slavonskom dijelu biskupije. Namještao je župnike i kapelane, koji su pred njim polagali župničke ispite. ${ }^{1}$ Iduće 1753 . godine biskup Thauszy obilazi kao vizitator slavonske župe i vodi sa sobom pučkog misionara Jurja Muliha, koji drži misije u 20 župa. Sâm biskup sudjeluje s Mulihom u misijama u Požegi, Cerniku i Pakracu. Kroničar je zabilježio da su premnogi pokornici tražili ispovijed, da su obraćeni razni zločinci, da je iskorijenjena psovka; da je propagiran kršćanski karitas, da su

1 Mijo Korade, Franjo Thauszy 1751-1769, u: Zagrebački biskupi i nadbiskupi, ŠK, Zagreb 1995, 205-211. 
obraćena tri pravoslavca i jedan musliman, a Mulih je krstio i po noći. ${ }^{2}$ Iste godine biskup je postigao da njegovi biskupijski svećenici preuzmu od franjevaca župu u Požegi i većinu ostalih župa u kraju, koje su do tada držali franjevci. Sada je trebalo organizirati pastoralni i katehetski rad po župama, pa se i za to pobrinuo biskup izdanjem novog katekizma. Tako sljedeće godine izlazi katekizam pod naslovom:

Obilato duhovno mliko. To jest: Nauk kerstianski iliričkoj iliti slovinskoj dičici darovan od njih ekscelencije prisvitloga i pripoštovanoga gospodina gospodina Frančeska Thauszyja po Božjoj i Apostolske stolice milosti BISKUPA ZAGREBAČKOGA. Pritiskano u Zagrebu po Antunu Reineru Hervatskoga Kraljevstva Pritiskaru Godišta 1754. (12, /8/+192 str.).

U poticajnom „Pridgovoru“, koji potpisuje biskup Thauszy, on obrazlaže svoju nakanu za vjerskom obnovom toga dijela biskupije pomoću župnika, donosi opširni poticaj njima i odraslima a osobito djeci da nauče vjerske istine. Naglašava svoje pravo da postavlja svoj kler za župnike: „Zato kaono sam nove duhovne pastire nikojim župama dao, tako ću s vrimenom i ostalim dati, koji će vas učiti." On bi najradije sam podučavao djecu kad bi mogao: „Tolika je gorućnost ljubavi i nastojanja moga, da bi ja isti svakoga napose, ako bi moguće bilo, učiti htio." Budući da to nije moguće daruje ovaj katekizam u ruke svećenika i svih koji znadu čitati s molbom da oni podučavaju ,i druge koji štiti ne znadu“.

Obraća se potom djeci: „Budući ja od Duha Svetoga stavljen vladati sa Stolnom Crkvom Zagrebačkom, između ostalih svetih briga, koje za Slavonie korist primam, vi mala Dičico, nejaki dio stada moga, poljubljene u Isusu ovčice, jeste jedna i osobita briga pastirske ljubavi moje!“ /.../ Tako i biskup po uzoru na Isusa koji je rekao „Pustite malene k meni..." naglašava: „Dakle i vas s istimi ričma ljubljeno zovem $\mathrm{k}$ meni, i ne samo vas malene u godinicah, nego li i osobitim načinom svekolike vas malahne i nejake u znanju Nauka Kerstianskoga, premda inačie vrimenite, željan vas učiti, što ste dužni znati i virovati, od kakva se zla uklanjati, kakvo li dobro činiti, što je u Zakonu kerstianskomu zabranjeno, što li je zapoviđeno, kako imate kerstianski živiti, da se i vi, ovčice moje, s onima srićnimi ovčicami /tj. s nevinom dječicom/ na dan sudnji ob desnu Pastira, Gospodina Isukrsta, saberete..."

„Budući da ste se (što je velike hvale vridno) primili nauka i pomnjivo se učite štiti, ufajući se ja, da će i drugi ovaj vaš pofaljeni u nauku izgled sliditi, zato vam ovu od Nauka Kerstianskoga knjižicu, s troškom mojim pritisnutu, darivam i poklanjam,

2 Ivan Fuček, Juraj Mulih, život i djelo, Zagreb 1994, Kronološka tablica misijskog rada Jurja Muliha, god. 1753. Sela i župe u kojima te godine Mulih drži misije: Požega, Cernik, Pakrac, Pleternica, Brekiniska, Gaj, Međurić, Kraljeva Velika, Jazavica, Bogićevci, Stara Gradiška, Kopanica, Orubica, Davor, Kobeš, Sibinj, Brod, Kutina, Garešnica i Osekovo. Mulih je u tom kraju držao misije i 1735. u četiri župe, a 1746. u oko 20 župa, također s velikim uspjehom. Spominje se da je 1735. misionar bosonog hodao s križem na leđima od misije do misije i da su ga mnogi slijedili noseći također križeve. Za 1746. je zabilježeno da je u Cerniku 348 muževa nosilo balvanske križeve u procesiji. 
koju poklanjajući 'Mliko sam za pitje dao vami' i ja mogu reći s Pavlom Apoštolom; ne samo mlađim nego i starim... 'Mliko obilato', u komu su svi nauci Zakona kerstianskoga tako razborito istomačeni da ji i priprosti lasno razumiti mogu. I prem da se nikoja u knjižici ovoj nahode, koja ditinski razum nadvisuju, i ako nisu sa svim potribita, doista su za obilatie nauka znanje veoma korisna... Štijte, ali ne trkomice, nego sabranom i skupljenom pametju, i druge, koji štiti ne znadu, učite, navlastito, kada su danci svečani, onda u šaljivu i taštu razgovoru ne dangubite, nego želji i nastojanju momu što naivećma možete, odgovarajte. Što ako li učinite, vi, koji ste sada briga moja, biti ćete radost i kruna moja."

Naglašava nakraju da se nada da će katekizmom unaprijediti taj kraj, koji je u prošlosti u mnogočemu zaostajao: „Ufam bo se, da Slavonia dosada po niki način pusta, odsele Naukom umitna i bogoljubstvom izglednia veselie procvate i plodnie se nakiti, i jasno od Slave ime, od toliko vikovah kanoti vlastito nosi, napridujući u nauku i bogoljubstvu još dostojnie uznosi. “3

Nekoliko pitanja i nedoumica postoje uz taj katekizam, od kojih neka i do danas nisu posve razjašnjena: Tko je autor katekizma, kome je namijenjen s obzirom na sadržaj, zašto nije imao kasnija izdanja i da li je to ustvari bio neuspio katekizam, osobito u usporedbi s kasnijom Kanižlićevom Bogoslovicom?

Što se autorstva tiče, neki su ga pripisivali biskupu Thauszyju (P. J. Šafarik, C. Sommervogel), neki i Mulihu (I. Kukuljević, Š. Ljubić, J. Badalić) ${ }^{4}$, a drugi (Adam Alojzije Baričević, Franjo Fancev, Tomo Matić) Kanižliću. Vanino se najprije kolebao i držao da ga je sastavio neki od požeških isusovaca i najvjerojatnije Kanižlić. ${ }^{5} \mathrm{U}$ sljedećem poglavlju istoga djela piše: „Može se uzeti kao stvar sigurna da je autor o. Antun Kanižlić koji je također jamačno stilizirao biskupove misli predgovora." ${ }^{\text {Još }}$ je sigurniji kasnije u trećem svesku svog djela kada kaže: „Pogrešno se pripisivalo inače zaslužnom biskupu Thauszyju, no nema nimalo sumnje da mu je autor Antun Kanižlić, član požeškoga kolegija. ${ }^{\prime 7}$

O namjeni i sudbini Mlika Vanino ima posebnu teoriju. Budući da su iste godine 1754. tiskana dva katekizma Mliko i Mulihova Pisanica duhovna (drugo izdanje ma$\log$ štokavskog katekizma iz 1734.), ${ }^{8}$ a dvije godine ranije je Josip Milunović započeo svoj projekt opismenjavanja požeškoga kraja, trebao je odlučiti koji katekizam mu je prikladniji za njegov rad. „Milunović je proučio Mliko, ako ne već u rukopisu, a ono svakako kad su stigli tiskani primjerci u Požegu, i uočio da taj katekizam ne može pot-

\footnotetext{
/A. Kanižlić/, Obilato duhovno mliko, Zagreb 1754, nepag. 4-8.

Josip Badalić, Juraj Mulih (1694-1754) Život i rad, Vrela i prinosi, 5 (1935) 122.

M. Vanino, Isusovci II, 636.

M. Vanino, Isusovci, II, 651.

M. Vanino, Isusovci, III, 441.

8 O tom katekizmu vidi Ivan Fuček, Juraj Mulih život i djelo, Zagreb 1994, 87-92.
} 
puno poslužiti njegovu radu po selima kako ga je on zamišljao. Prvo, jer je preopširan i drugo, jer se dobrim dijelom ne može na pamet učiti. Zato je posegnuo za kraćom Pisanicom i postigao, da ga bečka Katehetska biblioteka g. 1754. nanovo izda. Iz toga dašto ne slijedi da Milunović nije Mlika po selima dijelio starijima za čitanje. Ovo tumačenje pojave dvaju katekizma g. 1754. tek je hipoteza, jer suvremeni izvori o toj stvari šute. ${ }^{\prime \prime}$

S druge strane Emanuel Hoško, opisujući Kanižlićeve katekizme, primjećuje da se ne može oteti dojmu da on Mliko nije sastavio po svojem nahođenju i da je „najvjerojatnije slijedio shvaćanja i zahtjeve svojeg mecene biskupa Thauszyja i tako sastavio težak teološki katekizam koji je bez predloška i bez nasljednika u hrvatskoj katehetskoj literaturi. Zbog svih tih svojstava Obilato duhovno mliko nisu prihvatili ni vjeroučitelji ni vjeroučenici, a Kanižlić je ubrzo objavio novi katekizam pod naslovom Mala i svakomu potribna bogoslovica (1760/?/) koji je doživio sasvim drukčiju sudbinu... ${ }^{\prime 10}$ Takvu ocjenu sudbine dvaju Kanižlićevih katekizama ponavljaju i kasnije razni drugi autori.

Držim da se već iz samog gore citiranog predgovora može izvući nekoliko sasvim suprotnih zaključaka. Prvo, sasvim je logično da biskup Thauszy u katekizmu ističe svoj autoritet kao biskupa te od Boga mu povjerenu službu i brigu za svoje vjernike, jer time potkrijepljuje sve svoje druge inicijative (vizitacija, misije, postavljanje župnika i sl.) za obnovu i preporod slavonskoga dijela njegove biskupije. Zato se ističe njegovo ime i svi mogući naslovi i titule na naslovnici (velikim slovima: BISKUPA ZAGREBAČKOGA), pa se čak ističe i važnost tiskara (po Antunu Reineru Hervatskoga Kraljevstva pritiskaru) da se naglasi važnost knjige i onoga cilja zašto je tiskana. A osobito poticajni i poučni predgovor biskup „piše u svoje ime“ i potpisuje ga.

Drugo, u predgovoru je jasno naglašeno da biskup katekizam namijenjuje župnicima, koje je postavio, i ostalima koje će još imenovati, te ostalim odraslima da podučavaju djecu, koja su uglavnom bila nepismena. Treće, biskup veći dio predgovora posvećuje djeci koju nagovara i potiče da nauče čitati i potom temeljne vjerske istine, a pogotovo već u naslovu naglašava da je katekizam "dičici darovan“ od samog biskupa. Biskup i kasnije uz izdanje sinodalnih zaključaka Zagrebačke biskupije iz 1766. godine donosi stroge naredbe o podučavanju djece i odraslih. ${ }^{11}$ Poznate su i druge njegove akcije za školovanje i obrazovanje djece, koje su većinom ostvarivali požeški isusovci, ali je u svima sigurno važna bila i uloga biskupa Thauszyja, kao opismenjavanje djece u kutjevačkom kraju Josipa Milunovića i drugih (od 1752.), otvaranje osnovnih škola u Požegi (1753) i okolnim selima, osnivanje sjemeništa u Požegi (1754.), osnivanje visokog studija filozofije i teologije $u$ požeškom kolegiju (1760. i 1762.) i dr. ${ }^{12}$

\footnotetext{
M. Vanino, Isusovci, II, 639.

10 Franjo Emanuel Hoško, Negdašnji hrvatski katekizmi, Zagreb 1985, 90.

11 Franjo Thauszy, Constitutiones synodales dioecesis Zagrabiensis... Zagrabiae 1766, 49-61.

12 M. Korade, Biskup Franjo Thauszy, 408-409.
} 
Dakle, teško je govoriti o neuspjelom ili slučajno nepogođenom katekizmu, što je nužno povezano s njegovim autorstvom. Konačno je dilemu oko autorstva riješio Miljenko Belić, koji je isrpnom analizom teksta katekizma pokazao da je na više mjesta očito kako je Obilato duhovno mliko napisao Antun Kanižlić, a isto pokazuju i usporedbe s drugim njegovim djelima. ${ }^{13}$ Također je i u predgovoru Mlika prepoznatljiv Kanižlićev stil i način pripovijedanja kada govori o koristi kršćanskog nauka, o dužnostima kršćanskim, o potrebi pismenosti i sličnom.

A kakav je onda katekizam Kanižlić sastavio da bi ispunio očekivanja i namjenu biskupa te potrebe djece i odraslih onoga kraja? On, slijedeći osnovnu strukturu Kanizijevih katekizama (vjera, ufanje, ljubav, sakramenti i kreposti), u 25 poglavlja i u dijaloškom obliku pitanja i odgovora naširoko obrazlaže osnovna pitanja kršćanskoga nauka. Neki su odgovori vrlo opširni, prepuni teoloških termina a još više objašnjenjima vjerskih istina, vjerskih i crkvenih običaja i tradicije, kao što primjećuje Vanino: „Obiluje vrlo mnogim stvarima kojih nema u drugih Nauka krstjanskih, ili bar ne tako opširno i praktički obrađenih. Diktirale su ga životne prilike i potrebe piscu, koji je osluškivao bilo svog naroda i živo želio pomoći mu da se oslobodi raznih poroka i poživi lijepim kršćanskim životom.“ Zato se katekizam Mliko razlikovao „od drugih hrvatskih katekizama onoga vremena i sličnog opsega namijenjenih širim narodnim slojevima“" ${ }^{14}$ Kanižlić je tipični barokni pisac pun simbolike i bombastičnih izraza i slika, a pokazuje izvrsno poznavanje ljudi svoga kraja i onoga vremena. Često na slikovit način tumači i najobičnije stvari vjerskih običaja i vjerskog života, kao zašto se blagoslivaju voda i crkvena zvona, zašto se pale svijeće, koja je razlika između ružnih riječi ili naziva te psovki i proklinjanja itd. ${ }^{15}$ Slična će tumačenja i objašnjenja Kanižlić donositi kasnije u molitveniku Bogoljubnost molitvena (1766.), pa bi bilo zanimljivo analizirati s toga stanovišta njegove prozne tekstove, što vjerujem dosad nitko nije učinio.

Zato je takav katekizam imao smisla i opravdanja na početku vjerske obnove jednoga kraja jer je služio kao vodič u vjersko obrazovanje odraslih i djece te osnovni i korisni priručnik vjeroučiteljima. Sličnu su ulogu imali hrvatski prijevodi velikih katekizama Petra Kanizija, Roberta Bellarmina i Rimskog katekizma, kao i prvi originalni hrvatski katekizam Aleksandra Komulovića (1582.). ${ }^{16}$ Naravno da Mliko kao i drugi slični opširni katekizmi nisu mogli niti trebali imati istu recepciju i više izdanja kao mali popularni katekizmi za djecu, iz kojih su ona učila napamet vjerske istine $u$ školi i na vjeronauku, pa je potpuno nepotrebno uspoređivati ih.

\footnotetext{
Miljenko Belić, Tko je napisao „Obilato duhovno mliko“?, Vrela i prinosi, 13 (1982) 155-163.

M. Vanino, Isusovci, II, 638.

15 Opširni opis Mlika ima Franjo Emanuel Hoško, Negdašnji hrvatski katekizmi, Zagreb 1985, 86-90. Vidi i M. Vanino, Isusovci, II, 636-639.

16 Pregled tih izdanja vidi u F. E. Hoško, Negdašnji hrvatski katekizmi, 155-176.
} 


\section{Mala i svakom potribna Bogoslovica}

Šest godina nakon Mlika Kanižlić objavljuje Bogoslovicu, mali katekizam za školsku djecu, koji je doživio sedam izdanja. Prema riječima Tome Matića „po broju izdanja nije Bogoslovicu dostigla nijedna vjerska ni svjetovna knjiga slavonske književnosti u osamnaestom vijeku" ${ }^{17}$ Pogledajmo najprije naslov i izdanja katekizma, a potom razloge zašto je tada nastao i zašto je bio toliko popularan. Evo naslova četvrtog izdanja:

Mala i svakomu potribna BOGOSLOVICA, to jest NAUK KERSTJANSKI. U tri skule razdiljen, s-običajnima Molitvami, i Pismami, Za dicu, koja iđu u Skulu od Nauka Kerstjanskoga, Pritiskanje četvrto. Pritiskana u Ternavi 1766. (16 [24]+258+[6]).

Slijedeći podatke kronike požeškog kolegija, Tomo Matić i Vanino pretpostavili su da je prvo izdanje katekizma izašlo 1760., a drugo 1761. Vanino čak tvrdi da je katekizam prvi put „ugledao svjetlo svakako u prvoj polovini g. $1760 .{ }^{\prime 18}$ Od ta prva dva izdanja dosada se nije pronašao nijedan primjerak. Za treće izdanje Adam Alojzije Baričević u svojem rukopisnom popisu u Zagrebu tiskanih knjiga u 18. st. navodi: „Kanislich Antun, Mala i vsakomu potribna Bogoslovicza, to jest Navuk Kerstjanski, pritiskana vu Zagrebu od Josipa Schotler, 1763. - $12^{\mu 19}$ Franjevačka knjižnica na Trsatu posjeduje primjerak u kojemu se vidi da ima identičan naslov, a na kraju naslovnice stoji: „Pritiskanje treće“. A nakraju: U Zagrebu, Pritiskana od Josipa Schotler, 1763. (16 /24/+9+276 sa slikom). Primjerak je defektan, no očito je da ima isti sadržaj kao i četvrto izdanje. ${ }^{20}$ Iz istoga izdanja postoji, također defektan, primjerak u NSK u Zagrebu (bez naslovnice), pa je Vanino pogrješno mislio da je tiskano u Trnavi $1764 .^{21}$

Nakon četvrtog izdanja u Trnavi 1766., čiju sam naslovnicu gore donio, peto izdanje izlazi u Trnavi 1773., s identičnim naslovom i napomenom „Pritiskanje peto“ te istim formatom i brojem stranica ( $\left.16^{\circ}[24]+258+[6]\right)$. I šesto izdanje, tiskano u Trnavi 1800., ima identičan naslov i broj stranica, s napomenom na naslovnici „Pritiskanje šesto“. I sedmo izdanje, tiskano u Budimu 1818., na naslovnici je označeno kao šesto izdanje („,Pritiskanje šesto"), te vjerojatno zbog različitog sloga ima puno više stanica $\left(16^{\circ} \mathrm{VII}+384 \mathrm{str}\right.$.). ${ }^{22}$

Okolnosti zbog kojih Kanižlić objavljuje mali katekizam Bogoslovicu idu unazad nekoliko desetljeća i povezane su sa sustavnim i kontinuiranim nastojanjima požeških isusovaca oko opismenjavanja i vjerske pouke požeškog kraja, koje bih ovdje

17 Tomo Matić, Prosvjetni i književni rad u Slavoniji prije Preporoda, Zagreb 1945, 45

18 Tomo Matić, Život i rad Antuna Kanižlića, Stari pisci hrvatski, 26 (1940) XX-XXI, XXIX-XXXII; M. Vanino, Isusovci, II, 639-640, 659; III, 441.

19 Adam Alojzije Baričević, Catalogus librorum ab a. 1690 ad a. 1800 Zagrabiae impressorum, NSK, Zagreb, R 3660, list 30a.

20 Vatroslav Frkin i Miljenko Holzleitner, Bibliografija knjiga hrvatskih autora u knjižnicama Hrvatske franjevačke provincije sv. Ćirila i Metoda 1495.-1850., Zagreb 2008, 242.

21 M. Vanino, Isusovci, II, 659.

22 Evo ukratko u kojim se knjižnicama nalaze pojedina izdanja Bogoslovice: Franjevačke knjižnice imaju treće, peto i šesto izdanje (Frkin-Holzleitner, Bibliografija, 242-243.); Metropolitana, Zagreb ima četvrto i peto izdanje; Knjižnica HAZU, Zagreb, peto i sedmo izdanje; NSK Zagreb, treće i peto izdanje; Knjižnica "Juraj Habdelić“ Zagreb šesto izdanje i Sveučilišna knjižnica u Budimpešti četvrto izdanje. 
samo ukratko spomenuo. Već je 1727. pučki misionar Juraj Mulih u požeškom kraju poučavao u kršćanskom nauku na svojim misijama, a Kanižlić s drugima u Požegi desetljećima uspješno drži vjeronaučne poduke djeci i odraslima. Daju tiskati početnice za nepismene i male katekizme te ih besplatno dijele djeci i puku. ${ }^{23}$ Josip Milunović od 1752. pa sve do svoje smrti 1759. drži katehetske misije pod zaštitom sv. Franje Regisa ${ }^{24}$ u Požeškoj kotlini obilazeći sela i pašnjake te sustavno opismenjavajući seosku djecu i odrasle..$^{25}$

U isto vrijeme i sukladno tim akcijama osnivaju se, zaslugama biskupa Thauszyja $\mathrm{i}$ isusovaca, osnovne škole u Požegi, Kutjevu, Sesvetama i Kaptolu (na posjedu srijemskog biskupa Ivana Paxyja). Nasljednik Milunovića u katehetskim misijama u Požeškoj kotlini Juraj Barjaktari osniva 1760. Bratovštinu kršćanskoga nauka, koju požeški izvori nazivaju „Društva”. Ta su društva osnovana u mnogim selima, a posebno su napredovale u školama u Kutjevu i Sesvetama. U istim se školama organiziraju javni ispiti iz vjeronauka, pa tako kroničar spominje takove ispite 1761. u Kutjevu (dva) i Sesvetama, 1763. u Požegi, 1766. u Kaptolu i sl. Te su bratovštine osnivane po uzoru na one koje je od 1750. organizirao i vodio u Austriji isusovac i misionar Ignaz Parhamer. ${ }^{26}$

Svi su ti događaji i misijsko-prosvjetne akcije potaknule Kanižlića da 1760. objavi svoju Bogoslovicu. Budući da se nisu sačuvali primjerci prvog i drugog izdanja, ne znamo je li Kanižlić imao predgovor u tim izdanjima i kakav. U „Pridgovoru“ četvrtog izdanja (1766.) spominje kako je u prijašnjem trećem izdanju objasnio zašto je katekizam nazvao Bogoslovica, pa da to neće ponavljati. Prema tome, a i prema sačuvanim defektnim primjercima trećeg izdanja vidi se da je taj predgovor drugačiji od onog u četvrtom izdanju te se ponavlja sve do zadnjeg, sedmog izdanja.

Na početku predgovora Kanižlić izražava svoje razočaranje što trud misionara i vjeroučitelja oko vjerske poduke i opismenjavanja nema onog rezultata koji se očeki-

23 M. Vanino, Isusovci, II, 630-641. Vanino navodi iz kronika razna izdanja katekizamskih letaka i malih katekizama koji su nabavljani i dijelili se tih godina. Među ostalim to su bile Mulihove Abecevica (1748) i Pisanica duhovna $(1734,1754)$ i razne druge brošurice. Usp. I. Fuček, Juraj Mulih, Zagreb 1994, 101-104, 140143.; Zoran Velagić, Nepoznata Abecevica Jurja Muliha iz godine 1737., Vrela i prinosi, 21 (1996/97) 187-192.

24 Prilikom kanonizacije isusovačkog sveca, poznatog francuskog katehete i pučkog misionara sv. Ivana Franje Regisa (1597. - 1640.) 1737. godine austrijski su isusovci pokrenuli tzv. katehetske misije po njegovu uzoru i pod njegovom zaštitom.

25 Najbolje prikaze te akcije opismenjavanja imaju Franjo Fancev, Nekoliko crtica o analfabetskim tečajevima i ostalom pučko-prosvjetnom radu požeških isusovaca XVIII. vijeka, Jugoslavenska njiva, VI (1922) 181-193, 365-380, 455-462; M. Vanino u poglavlju „Pučko-prosvjetni rad“ požeškog kolegija u: Isusovci, II, 642668. Vidi i M. Korade, Katehetska pouka hrvatskih pučkih misionara od 16. do 19. stoljeća, Kateheza 19 (1997) br. 2, str. 129-133; isti, Shvaćanje prosvjete u vjerskim djelima sjeverne Hrvatske u 18. stoljeću, Mogućnosti 43 (1996) br. 7-9, str. 105-113.

26 Ignaz Parhamer (1715. - 1786.) misionar i glavni organizator novog tipa Bratovštine kršćanskoga nauka u vojničkome duhu i pisac brojnih katekizama. O bratovštini u požeškome i drugim krajevima vidi M. Korade, Bratovština kršćanskoga nauka u Hrvata u 18. stoljeću - Prilog povijesti laičkoga apostolata, Kateheza, XVII (1995) br. 3, 220-229. 
vao i ponovno potiče djecu da idu u školu i uče čitati: „Posli tolika neumorna truda, posli izgovorenih u crkvi molitava svaku nedilju i svetkovinu, posli tolikih Nauka kerstjanski, ima jih, koji još ne znadu pravo Otčenaša i Virovanja. Zašto? Običavali su nikoji odgovoriti: Ja toga pod sidu glavu ne naučih; što sam naučio, naučio sam, višje ne mogu. Ali to je očita laž da ne bi mogli. Naučio je ove tvrde i tupe glave Meštar Batina. O da bi ovi velemogući Meštar, kada inačie ne more biti, po selih učio, kako bi lipo cvala kerstjanska sela! Zato, da i dica, opakih ovih traga mladice, ne rastu kao njihovi roditelji, po samu imenu kerstjani, knjiga ova opet ide na svitlost, kao novi svidok, da neima prečega načina za naučiti pravo Nauk kerstjanski, nego idjući u Skulu i Knjigu učeći."

Zatim spominje škole u Kutjevu, Sesvetama, Požegi i Kaptolu koje lijepo napreduju, a na prigovore da djeca nemaju vremena ići u školu zbog mnogih poslova koje moraju obavljati on odgovara: „Nisam ja ovde metnuo ova zato, da sva imaju napamet dičica učiti, nego sam mloga i osobita skupio, da kada su prezaposlena, kako u Svetac, štiu i poslie, kada u skulu već ne idju, da uče iz ove knjižice, budući da se malo knjiga nahodi našim jezikom od Nauka kerstjanskoga." A one koji prigovaraju da je njegova knjižica preteška upućuje na Bellarminov i Rimski katekizam, ${ }^{27}$ pa nastavlja: „Ova pročtivši, ako je zriloga mozga, neće mi prigovarati. Što je pako porad istoga učenja, složnik knjige od svetoga Aloizia u Pridgovoru ${ }^{28}$ one prazne razloge protresavši i prošibavši knjigozlobnikom usta jest zaključao. “29

Bogoslovica ima vrlo bogat sadržaj i zapravo nije samo katekizam nego i molitvenik i pjesmarica, kako je navedeno već u naslovu. I takav trostruki sadržaj upotpunjuje svrhu djela kakvu je pisac namijenio djeci požeškog kraja: dao im je uz katekizam molitve i pjesme koje će lakše naučiti uz misionare promicatelje opismenjavanja i vjerske poduke te župnike i druge učitelje. Tako Bogoslovica sadrži: 1. Nauk krstjanski (str. 1-144, u tri skule: $28+48+68$ str.), 2. Molitve običajne (42 str.), 3. Pisme bogoljubne koje se u nedilju i svetkovine, a osobito u vrime s. poslanja običaju pivati (72 str.), 4. Ministrovanje (služba za ministrante, nepagin. 6 str.).

Sâm je katekizam, podijeljen na tri škole, kako stoji u naslovu, prijevod, zapravo prerada njemačkog katekizma spomenutog austrijskog katehetskog misionara i pro-

27 Mogao je misliti na prijevod malog Bellarminova katekizma od slavonskog franjevca Šime Mecića, pa na preradu Rimskog katekizma franjevca Emerika Pavića, ili na razna dalmatinska izdanja Komulovića, Kašića i drugih. Vidi ovdje bilj. 16.

28 Time upućuje na djelo Šest nedilja na poštenje sv. Aloizie Gonzage, Zagreb 1759. Josipa Milunovića koji u glasovitom predgovoru pobija prigovore seljaka protiv pismenosti i škola, a donosi mnoge argumente o potrebi i nužnosti školovanja i vjerske poduke. Taj je predgovor u 20. stoljeću često pretiskivan u raznim antologijama i zbirkama. Usp. M. Vanino, Isusovci, II, 652-659; Ivan Kevrić, O. Josip Milunović, život i djelo, Zadar 2011.

29 Antun Kanižlić, Mala i svakom potribna Bogoslovica, 4. izd. Trnava 1766, Pridgovor, nepaginirano. Vanino prenosi čitav tekst predgovora, ali iz petog izdanja (1773.). M. Vanino, Isusovci, II, 662-663. 
micatelja Bratovštine kršćanskog nauka Ignaza Parhamera. Taj je katekizam sastavljen u tradiciji katekizama sv. Petra Kanizija i prilagođen je školskoj djeci i članovima spomenute bratovštine. ${ }^{30}$ Podjela u tri skule zapravo je gradivo vjeronauka podijeljeno u tri razreda. Zato je njezin sadržaj opširniji u drugoj i još više u trećoj skuli. Omogućuje postupno učenje prema uzrastu, a i poticaj je djeci za prolazak u višu skulu. Zapravo se u svakoj skuli na svoj način i primjereno uzrastu tumače glavne vjerske istine, a treća skula obuhvaća tumačenje Vjerovanja, Očenaša, Dekaloga, sakramenata i „,dužnosti pravde kršćanske“. Zato Hoško primjećuje: „Ova treća ,skula” tako predstavlja gradivo cjelovitog kanizijevskog katekizma, dok je druga ,skula' izbor onih dijelova koji su neposredno upravljeni pripravi za prvu ispovijed i pričest. ${ }^{\text {"31 }}$

\section{Dvije varijante Male i svakome potribne Bogoslovice}

Okolnost zbog koje je 1761. objavljen sličan Bogoslovici i gotovo isti katekizam, ali namijenjen bačkim Hrvatima, bila je kanonska vizitacija koju je te godine obavljao kaločki nadbiskup grof Joseph Báttyany u svojoj nadbiskupiji i za to je pozvao tri isusovačka misionara da drže pučke misije za mađarske, njemačke i hrvatske vjernike. Od Hrvata je pozvan Petar Lipovčić, prijašnjih godina dalmatinski misionar, a te $\mathrm{i}$ iste godine djeluje u Požegi. Najprije su hrvatski i mađarski misionar uz njemačkoga upoznali katehetske misije po Parhamerovoj metodi, a potom su se razdvojili. Lipovčić drži misije u mjestima Baja, Dušnok, Szent Maria, Gara, Hercegszanto (Santovo), Beregg i Rullod. Svugdje misionari uvode Bratovštinu kršćanskoga nauka, narod je dolazio na misije iz okolnih mjesta u velikom broju, a u Baji je na procesiji bilo oko 11.000 ljudi. Nadbiskup je dao tiskati i razdijeliti preko 2.000 katekizama s uputom za nepismene i crkvenim pjesmama. Otvorio je nekoliko škola u kojima su djeca mogla steći prvu naobrazbu. Da je uspjeh ubrzo postao očit, pokazuje podatak da su djeca svoje ukućane učila čitati i pisati i da su im pjevala pobožne pjesme. ${ }^{32}$ Katekizam koji spominje kronika nosi naslov:

Nauk karstjanski sverhu pet poglavjah Petra Canisia Družbe Isusove na pitanja i odgovore za tri skule razdiljen, s običajnima molitvami, s različitih pismah, s naredbami Bratinstva od nauka kerstjanskoga i proštenjih... U vrime pako svetih misionah po jednomu iz Družbe Isusove misionaru podiljen godine 1761. Pritiskan u Zagrebu od Gajetana Härl. $\left(16^{\circ}, / 24 /+238\right.$ str. $)$.

Na početku je dugačak predgovor kaločkog nadbiskupa Josepha Báttyanyja koji je potpisao 16. travnja 1761. (str. nepag. 2-11), a zatim su kratka pravila Bratovštine

\footnotetext{
30 Ignaz Parhamer, Der Katechismus mit den drei Schulen und gewönlichen Gesängen, Wien 1750.

31 F. E. Hoško, Negdašnji hrvatski katekizmi, 90-91.

32 Opširno o misijama i katekizmu za bačke Hrvate vidi u M. Korade, Bratovština kršćanskog nauka, 226227.
} 
kršćanskog nauka: „Občinske naredbe i dužnosti bratinstva“ (nepagin. 11-24). Nadbiskup preporučuje župnicima da redovito poučavaju kršćanski nauk i uvode bratovštinu prema običajima i naredbama razloženim u toj knjizi. Zatim nastavlja: „Tri vrućeželjna misnika Družbe Isusove vami onomadne poslasmo, koji budući da su $\mathrm{s}$ neumornim nastojanjem svojim rečeno Bratinstvo u drugih biskupijah srićno podignuli, uzdamo se brez svake sumnje da će oni i u deržavi našeg arcibiskupata ovi posao srično kako želimo obaviti..." Potom nadbiskup naređuje da djeca u školi uče vjeronauk po toj knjizi. Po napomeni na početku uputa o Bratinstvu vidi se da ih je sastavljač uzeo iz pravila bečke bratovštine: „Ove kratke naredbe u Bratinskoj knjigi koja se u kući od profesah Družbe Isusove u Beču nahodi, jesu obilato istumačene."

Taj vjerojatno prvi školski udžbenik bačkih Hrvata, nakon uvodnog dijela, sadrži katekizam (str. 1-151), običajne molitve (151-194) i „pisme bogoljubne koje se u vrime svetoga poslanja pivaju“ (195-238). Tekst katekizma isti je kao i u Kanižlićevoj Bogoslovici, s razlikom što su u Nauku malo skraćene upute na početku pojedinih poglavlja. Također su malo skraćene molitve, manje ima i pjesama i nešto su drukčije, ali većinom su, osobito marijanske, pjesme Kanižlićeve, kao npr. Pismu novu svi pivajmo i druge. Zato je očito da je i taj katekizam Kanižlićevo djelo, a s obzirom na to da ga je Lipovčić dijelio na bačkim misijama, možda je i on sudjelovao u priređivanju toga izdanja.

Taj je katekizam doživio i drugo izdanje s istovjetnim naslovom i nastavkom naslovnice: „U vrime pako svetih misionah po jednomu iz Družbe Isusove misionaru podiljen godine 1766. U Kalači, Slovima Arcibiskupovih po Ivanu Josipu Wagner, 1767“ $\left(16^{\circ}, / 28 /+255 \text { str. }\right)^{33}$ Vidi se po naslovu da je katekizam ponovno tiskan u sjedištu Kaločke nadbiskupije, što je vjerojatno bila zasluga tamošnjeg nadbiskupa. Zanimljivo je spomenuti da je Petar Lipovčić, rođeni Požežanin, upravo samo te 1766. godine ponovno na službi propovjednika u Požegi, jer je nakon prvog boravka (1761. - 1762.) u Požegi, službovao u Trnavi i nakon 1766. u Varaždinu. ${ }^{34}$ Tako je vjerojatno opet on držao misije u Kaločkoj nadbiskupiji i dijelio drugo izdanje katekizma.

Jedva je dosad bilo poznato da je Kanižlićeva Bogoslovica doživjela i jedno kajkavsko izdanje. ${ }^{35}$ Priredio ga je zagrebački kanonik Baltazar Mataković (1725. - 1773.), ${ }^{36}$ a puni mu je naslov (u originalnoj grafiji): Naruchna knisicza navuka kerschanskoga vu prilike razgovora med navuchitelom, y vuchenikom, z-dareslivosztjum ovde neimenovanoga

33 Ima ga franjevačka knjižnica u Kloštar Ivaniču. Vidi Frkin-Holzleitner, Bibliografija, 356. Zanimljivo da za to drugo izdanje katekizma zna pisac natuknice o bratovštinama u ratnoj Hrvatskoj enciklopediji, navodeći da je 1767. Kaločka nadbiskupija izdala poseban molitvenik za bratovštinu, dok se malo kasnije $\mathrm{u}$ istom članku navodi kao Nauk krstjanski s naredbama bratovštine iz 1767. Usp. HE, III, 249-250.

34 Vidi Ladislaus Lukács, Catalogus generalis seu Nomenclator biographicus personarum Provinciae Austriae Societatis Iesu (1551-1773), Pars II, Romae 1988, 891.

35 Prvi je na taj prijevod kratko s jednom rečenicom upozorio F. E. Hoško, Negdašnji hrvatski kaekizmi, 91.

36 Usp. Leksikon hrvatskih pisaca, Zagreb 2000, 466. 
dobrochinitela na szvetlo dána. Iz slavonszkoga na horvaczki hisni jezik prenessena, y iz drugeh szkup szlosena po Boltisaru Mattakovichu, kanoniku zachessanszkom, y czirkve farne B. D. M. vu Kaptolom zagrebechkom plebanushu. - Pritiszkana vu Zagrebu po Antunu Jandera, letto 1770, $\left(16^{\circ},[24]+312+[12]\right.$ str. $) .^{37}$

Prevoditelj i priređivač katekizma kanonik Mataković ni u naslovu ni u predgovoru ne navodi čije je djelo priredio na kajkavskom. U naslovu samo kaže da je „iz slavonskoga na horvatski hižni jezik prenesena, i iz drugeh skup složena“.To bi značilo da je preveo jedno djelo sa slavonskog (tj. štokavskoga) i nadopunio drugim knjigama. U predgovoru uopće ne govori otkuda je uzeo predložak već samo ističe važnost učenja kršćanskog nauka i potiče na bolji vjerski život. Nakon predgovora na nepaginiranim je stranicama uobičajeni kalendar.

Djelo obuhvaća tri dijela. U prvom je katekizam podijeljen u tri škole (str. 1-149), koji ima Priložek iliti način za spoved potreben. To su molitve i pouke za ispovijed i pričest (149-171). Drugi dio ima Navuk za četertu školu svete meše. To nisu samo pobožnosti i molitve za svetu misu nego i razne druge pobožnosti i pouke: Zavjetek navuka pričeščenja (199), Navuk od greha smertnega (210), Navuk osebujni od običajev Svete Matere Cirkve - to su obredi i vjerski običaji Velikog tjedna (222), Priložek občinski od običajeh mertveh (245). Treći dio pod naslovom: Del trejti od molitvih navadnih i popevkih sadrži običajne molitve (jutarnje, večernje, pod misom), litanije imena Isusova, litanije lauretanske te razne molitve svecima. Među popevkama je i Popevka vu kojoj mladenci Jezusa deklice Mariji u izminjanju i svi skupa hvale. To je Kanižlićeva poznata pjesma Pismu novu svi pivajmo. Druge pjesme, kao prije propovijedi, o smrti, sudu, paklu uglavnom su Kanižlićeve. U zadnjim nepaginiranim stranicama je Ministrovanje, Tebe Boga hvalimo i Tabula pitagorika", to jest tablica množenja.

Prema tom pregledu sadržaja Matakovićeva kajkavskog prijevoda očito je da je katekizam u tri škole preuzeo iz Kanižlićeve Bogoslovice. Ostali dijelovi Naručne knjižice, kao priprava za ispovijed i pričest, pobožnosti svete mise, a osobito crkveni obredi Velikog tjedna, pobožnosti mrtvima i dušama u čistilištu, preuzeti su iz Kanižlićeva molitvenika Bogoljubnost molitvena. Molitve i pjesme mogao je uzeti jednako iz Bogoslovice i molitvenika. Detaljnom analizom i usporedbom Kanižlićevih i Matakovićevih tekstova moglo bi se ustanoviti d je li Mataković baš sve doslovno prevodio i otkuda i je li preuzeo nešto iz drugih štokavskih katekizamskih i molitvenih djela. Moj je dojam da je kanonik Mataković tim kajkavskim izdanjem htio pružiti najljepše i po njemu najkorisnije stranice Kanižlićeva katekizma i molitvenika. To pokazuje koliko su ta Kanižlićeva djela imala odjeka ne samo u požeškom i slavonskom kraju, za koji je pisao i posvetio mu veći dio svoga života.

37 Primjerak ima Nacionalna i sveučilišna knjižnica u Zagrebu. 


\section{Zaključak}

Iz svega obrazloženoga u ovome radu razvidno je da su dva Kanižlićeva katekizma, premda su imala isti cilj i tematski sadržavala isto gradivo, bila posve različita po načinu obrade vjerskog sadržaja i namjeni. Katekizam Mliko zamišljen je kao svjedočanstvo i zauzimanje biskupa Thauszyja za vjersku obnovu slavonskoga dijela Zagrebačke biskupije, zato Kanižlić sastavlja opširan i teološki bogat katekizam, ali prilagođen vjerskoj tradiciji i običajima toga kraja. A Bogoslovicu Kanižlić namjenjuje školskoj djeci s katekizmom, molitvenikom i pjesmama, što je mladeži bilo nužno i korisno u njihovu vjerskom obrazovanju. Budući da su, zahvaljujući biskupovim i isusovačkim nastojanjima, vjerski odgoj i obrazovanje bili tih desetljeća u punom zaletu u tom dijelu Hrvatske, tako je i potreba za novim izdanjima Bogoslovice bila sasvim logična. Ali je njezina popularnost, a i potreba, prelazila granice Slavonije u dva izdanja za bačke Hrvate i prijevodom na kajkavski jezik. Tako je taj katekizam zapravo doživio deset izdanja i proširio svoj utjecaj na hrvatskog mladog čitatelja od današnjih slovenskih pa sve do rumunjskih granica.

\section{Izvori i literatura}

Adam Alojzije Baričević, Catalogus librorum ab a. 1690 ad a. 1800 Zagrabiae impressorum, rkp. u NSK, Zagreb, R 3660.

/Antun Kanižlić/, Obilato duhovno mliko, Zagreb 1754.

Antun Kanižlić, Mala i svakom potribna Bogoslovica, 4. izd. Trnava 1766

Josip Milunović, Šest nedilja na poštenje sv. Aloizie Gonzage, Zagreb 1759.

Ignaz Parhamer, Der Katechismus mit den drei Schulen und gewönlichen Gesängen, Wien 1750.

Franjo Thauszy, Constitutiones synodales dioecesis Zagrabiensis..., Zagrabiae 1766.

Josip Badalić, Juraj Mulih (1694-1754) Život i rad, Vrela i prinosi, 5 (1935) 93-126.

Miljenko Belić, Tko je napisao „Obilato duhovno mliko“?, Vrela i prinosi, 13 (1982) 155163.

Franjo Fancev, Nekoliko crtica o analfabetskim tečajevima i ostalom pučko-prosvjetnom radu požeških isusovaca XVIII. vijeka, Jugoslavenska njiva, VI (1922) 181-193, 365380, 455-462.

Vatroslav Frkin i Miljenko Holzleitner, Bibliografija knjiga hrvatskih autora u knjižnicama Hrvatske franjevačke provincije sv. Ćirila i Metoda 1495.-1850., HAZU, Zagreb 2008.

Ivan Fuček, Juraj Mulih, život $i$ djelo, FTI, Zagreb 1994.

Hrvatska enciklopedija, III, Zagreb 1943.

Franjo Emanuel Hoško, Negdašnji hrvatski katekizmi, Zagreb 1985.

Ivan Kevrić, O. Josip Milunović, život i djelo, Zadar 2011.

Mijo Korade, Franjo Thauszy 1751-1769, u: Zagrebački biskupi i nadbiskupi, ŠK, Zagreb 1995. 
Mijo Korade, Bratovština kršćanskoga nauka u Hrvata u 18. stoljeću - Prilog povijesti laičkoga apostolata, Kateheza, 17 (1995) br. 3, 220-229.

Mijo Korade, Shvaćanje prosvjete u vjerskim djelima sjeverne Hrvatske u 18. stoljeću, Mogućnosti 43 (1996) br. 7-9, 105-113.

Mijo Korade, Katehetska pouka hrvatskih pučkih misionara od 16. do 19. stoljeća, Kateheza 18 (1996) br. 4, 307-319; 19 (1997) br. 2, 127-135.

Leksikon hrvatskih pisaca, ŠK, Zagreb 2000.

Ladislaus Lukács, Catalogus generalis seu Nomenclator biographicus personarum Provinciae Austriae Societatis Iesu (1551-1773), Pars II, Romae 1988.

Tomo Matić, Pjesme Antuna Kanižlića, Antuna Ivanošića i Matije Petra Katančića, Stari pisci hrvatski, 26, MH, Zagreb 1940.

Tomo Matić, Prosvjetni i književni rad u Slavoniji prije Preporoda, HAZU, Zagreb 1945.

Zoran Velagić, Nepoznata Abecevica Jurja Muliha iz godine 1737., Vrela i prinosi, 21 (1996/97) 187-192.

Zoran Velagić, Štokavska početnica Jurja Muliha iz 1737. godine, Gazophylacium, V, 1-2, (2000) 16-48.

Miroslav Vanino, Isusovci i hrvatski narod, (priredio za tisak i dopunio M. Korade), II, FTI, Zagreb 1987; III, FTI, Zagreb 2005. 


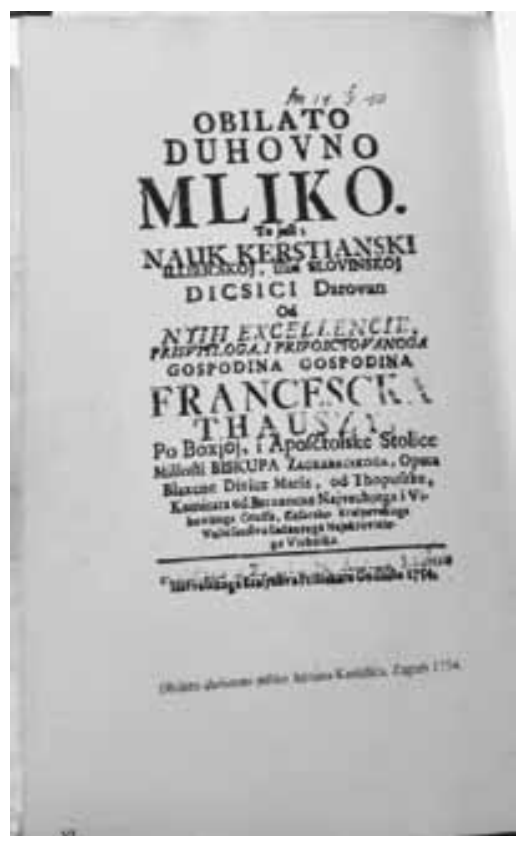

Slika 1. Obilato duhovno mliko

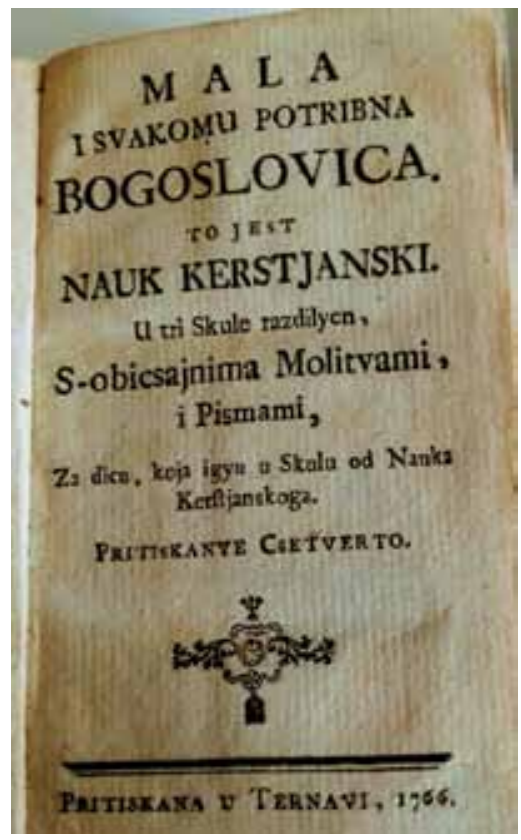

Slika 2. Bogoslovnica 1766. (4. izd.) 
Radovi Zavoda za znanstveni i umjetnički rad u Požegi, 8 (2019), str. 33-49 M. Korade: Okolnosti, izvori i dometi katekizama Antuna Kanižlića

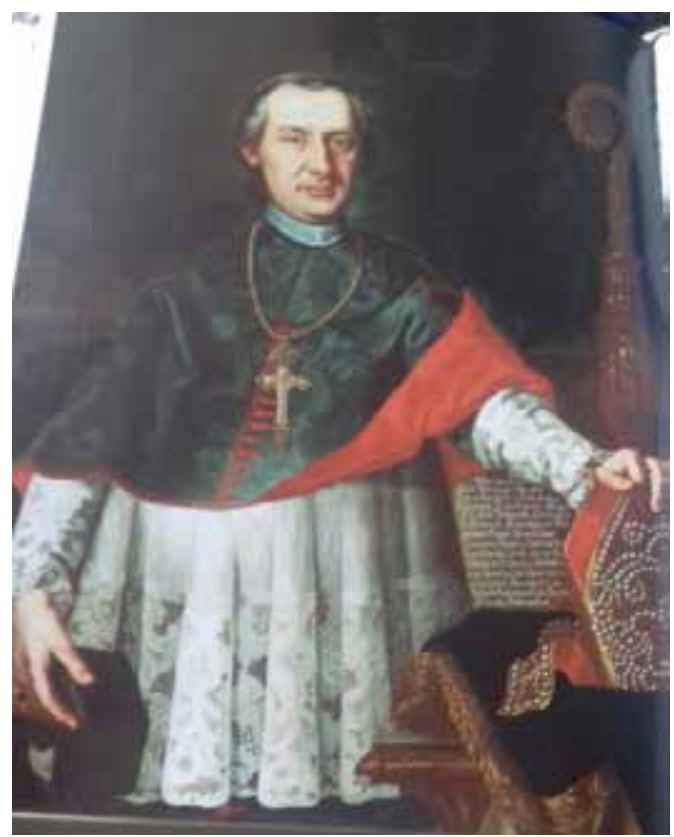

Slika 3. Slika biskupa Thauszya

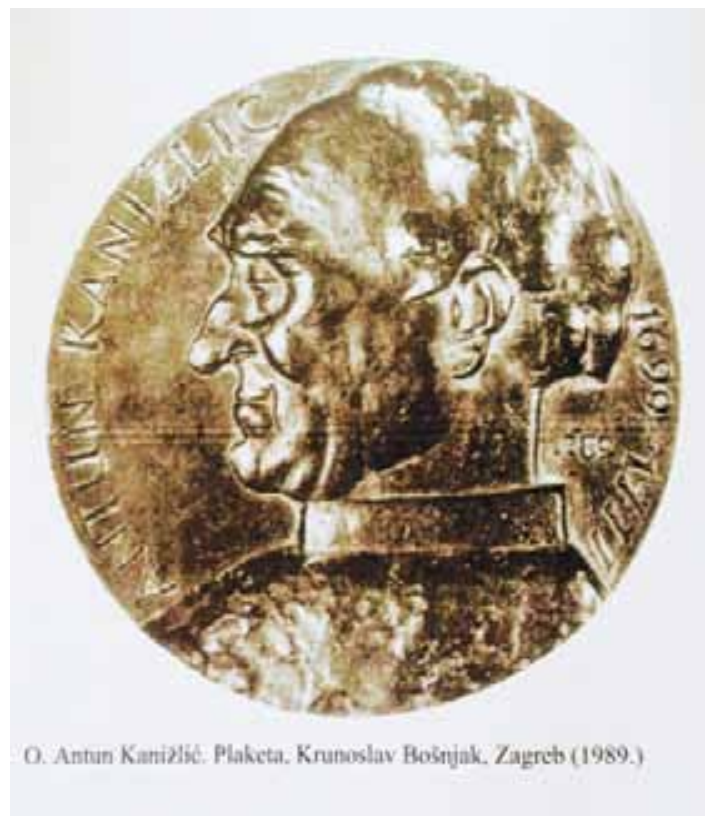

Slika 4. Kanižlić medaljon 


\section{Circumstances, Sources and Achievements of Kanižlić's Catechisms}

\section{Summary}

Kanižlić published two catechisms. Though each of them was written in different circumstances and had different destinies, their role and value in the religious and cultural life of Slavonia in that period was the same. The paper explains and offers new information concerning the circumstances, sources and achievements of Kanižlić's catechisms. The first of the two catechisms, entitled Obilato duhovno mliko. To jest Nauk krstjanski iliričkoj iliti slovinskoj dičici darovan (Zagreb 1754), was written on the occasion of a series of missionary's visits organised by the Zagreb Bishop Franjo Thauszy in 1753 in the Požega area. A year before that, he elected Kanižlić President of the Diocesan Consistorium in Požega, and thus the catechism was published under the Bishop's name. It includes an inspired and stimulative foreword written by the Bishop. The structure of the book follows Peter Canisius's great catechism. Its content is profoundly theological, organised in 25 chapters in the form of questions and answers; it is explained why the book is intended for parish priests and teachers, and why no further editions were published. The second catechism was entitled Mala i svakom potribna bogoslovica. To jest Nauk kerstjanski u tri skule razdiljen. The first edition was probably published in 1760 . There had been seven editions until the year 1818 . The book includes catechism, prayers and poems. It was written at the time of the action against illiteracy launched in the Požega area in 1752 by Josip Milunović, the first elementary schools opened in this region, and the Fraternity of Christian Study, organised and led by the Jesuits since 1760. Thus, this catechism is in fact rewritten German catechism originally written by Ignatius Parhammer, initiator and promoter of this catechist movement in Austria, which by method follows Canisius's tradition. Furthermore, in 1761, a catechism with identical content was published in Zagreb under the title Nauk karstjanski sverhu pet poglavjah Petra Canizija Družbe Isusove na tri skule razdiljen... The title itself indicates that in addition to catechism, prayers and poems, the book includes instructions for the Fraternity of Christian Study as well. It was the Jesuit Petar Lipovčić who was distributing it during his missions among the Croats in the Bačka region. Joseph Báttyany, Archbishop of Kalocsa, wrote a comprehensive foreword thereto. He stated that on his visits, he distributed more than 2,000 copies of the catechism and instructions for illiterate persons. The same catechism was again published in Kalocsa in 1767 in order to serve the same purpose, with a remark that missionaries distributed it on their visits in 1766. Boltižar Mataković, canon of Zagreb, translated Kanižlić's Bogoslovica into Kajkavian and published it under the title Naručna knižica navuka krščanskoga (Zagreb 1770).

Keywords: Antun Kanižlić; Slavonia; $18^{\text {th }}$ century; catechisms; Franjo Thauszy; Fraternity of Christian Study.

Prof. dr. sc. Mijo Korade, profesor emeritus

Fakultet hrvatskih studija Sveučilišta u Zagrebu

Borongajska cesta 83d, 10000 Zagreb

mkorade@hrstud.hr 
